\title{
Forage production and mineral composition of cactus intercropped with legumes and fertilized with different sources of manure
}

\author{
Karina Rodrigues de Miranda ${ }^{1^{*}}$ (iD) José Carlos Batista Dubeux Junior ${ }^{2}$ \\ Alexandre Carneiro Leão de Mello $^{3}$ Maria da Conceição Silva ${ }^{4}$ \\ Mércia Virginia Ferreira dos Santos $^{3}$ Djalma Cordeiro dos Santos ${ }^{4}$
}

'Departamento de Zootecnia, Universidade Federal Rural de Pernambuco(UFRPE), 52171900, Recife, PE, Brasil. E-mail: karina_miranda18@hotmail.com. ${ }^{*}$ Corresponding author.

${ }^{2}$ University of Florida (UF), Marianna, FL, EUA.

${ }^{3}$ Departamento de Zootecnia, Universidade Federal Rural de Pernambuco (UFRPE), Recife, PE, Brasil.

${ }^{4}$ Instituto Agronômico de Pernambuco (IPA), Arcoverde, PE, Brasil.

ABSTRACT: The objective of this study was to evaluate the productive potential and mineral composition of the forage cactus IPA-Sertania (Nopalea cochenillifera Salm Dyck). This species was analyzed both in monoculture and intercropped with leucaena [Leucaena leucocephala (Lam.) De Wit.] and gliricidia [Gliricidia sepium (Jacq. Steud.], and was assessed with different sources of manure (cattle, sheep, goat, and broiler litter) serving as fertilizer. The experiment was conducted at the Experimental Station of the Instituto Agronomico de Pernambuco in Caruaru, PE, Brazil. Treatments were allocated in a split-plot arrangement in a randomized complete block design, with four replications. Main plots consisted of cropping systems, while the split-plots were dedicated to manure sources. Cactus harvest was carried out after two years of regrowth. Response variables included both production and nitrogen (N), phosphorus (P), potassium (K), calcium (Ca), and magnesium $\mathrm{Mg}$ ) concentrations. No differences were observed for cactus production between the cropping systems, with an average value of $22.1 \mathrm{Mg}$ dry matter $\mathrm{ha}^{-1} 2$ years $^{-1}$. In the intercropped systems, greater proximity to the legumes increased the production of the cactus in the treatments with the cattle and sheep manure, and increased the concentrations of $P, K$, and $\mathrm{Mg}$, but not of $\mathrm{N}$. The introduction of tree legumes, along with the application of manure, contributes to an increase in production and nutrient concentration of IPA-Sertânia cactus.

Key words: fertilizer, intercropping, minerals, Nopalea, production.

Produção de forragem e composição mineral da palma consorciada com leguminosas e adubada com diferentes fontes de esterco

RESUMO: Objetivou-se avaliar o potencial produtivo e a composição mineral da palma forrageira IPA-Sertânia (Nopalea cochenillifera Salm Dyck), em cultivo isolado e consorciada com leucena [Leucaena leucocephala (Lam.) de Wit.] ou gliricídia [Gliricidia sepium (Jacq.) Steud.], e adubada com as fontes de esterco bovino, ovino, caprino e cama de frango. O experimento foi conduzido na Estação Experimental do Instituto Agronômico de Pernambuco - IPA, em Caruaru. O delineamento foi casualizado em blocos, em parcelas subdivididas, com quatro repetições. As parcelas foram representadas pelos sistemas de cultivo e as subparcelas pelas fontes de esterco. A colheita da palma foi realizada aos dois anos de crescimento e analisada quanto à produção e aos teores de nitrogênio ( $N)$, fósforo ( $P$ ), potássio $(K)$, cálcio (Ca) e magnésio (Mg). Não foram observadas diferenças de produção da palma entre os sistemas de cultivo, atingindo valor médio de 22,1 t ha ${ }^{-1}$ 2 anos $^{-1}$ de matéria seca (MS). Nos sistemas consorciados, a maior proximidade com as leguminosas incrementou a produção da palma, nos tratamentos com os estercos bovino e ovino, e elevou os teores de P, K e Mg, mas não os teores de N. A introdução de leguminosas arbóreas, juntamente com a aplicação dos estercos, contribui para elevar a produção e os níveis de nutrientes da palma IPA-Sertânia.

Palavras-chave: adubação, consórcio, minerais, Nopalea, produção.

\section{INTRODUCTION}

The spineless cactus IPA Sertânia (Nopalea cochenillifera Salm Dyck) is characterized by its tolerance to arid conditions, high water use efficiency, increased biomass production potential, and resistance to the prickly pear cochineal (LOPES et al., 2010). It is commonly used in the semiarid region of the Northeast Region of Brazil in order to increase forage production and guarantee feed for herds during periods when less is available. Its cladodes are rich in energy, water, minerals, and vitamins; although, it has a low crude protein concentration of $4.8 \%$ and a low concentration of 
fiber (neutral detergent fiber $=26.8 \%$; acid detergent fiber $=18.8 \%$ ) (FERREIRA et al., 2012).

Introduction of forage legumes into cactus cultivation can complement animal diets by offering protein and fiber, as well as increasing $\mathrm{N}$ availability via biological nitrogen fixation or the decomposition of the corresponding litter, roots, and nodules. Leucaena [Leucaena leucocephala (Lam.) de Wit.] and gliricidia [Gliricidia sepium (Jacq.) Steud.] are tree legumes adapted to the semiarid regions. They present high crude protein (averaging 18 to $30 \%$ in their leaves) and biomass production, and can be consumed by ruminants (EDWARDS et al., 2012).

In addition to the intercropping combination, soil fertility management is a main factor in cultivar productivity, particularly in arid and semiarid regions; the corresponding soil generally contains low quantities of organic material. Spineless cacti extract a large quantity of nutrients (DUBEUX JUNIOR et al., 2006) from soil. In addition, their cladodes are taken from the area where they are grown and provided to animals via trough feeding. As such, nutrients are not replaced, which, combined with erosion, tends to diminish productivity after continuous use (RAMOS et al., 2015).

Manure can serve to add organic material to soil, providing plants with nutrients and increasing overall cactus production. Generally speaking, an abundance of organic matter increases the dry matter production of forage cactus. Various studies have assessed manure quantity and source (SANTOS et al., 1996), and have reported linear increases in production up to $80 \mathrm{Mg} \mathrm{ha}^{-1}$ of cattle manure applied every two years, with plant density varying from 20,000 to 160,000 plants ha ${ }^{-1}$ (SILVA et al., 2016). However, manure type has not been studied for cropping systems using tree legumes.

As such, the objective of this research is to evaluate the productive potential and mineral composition of the IPA-Sertânia forage cactus when intercropped with leucaena and gliricidia tree legumes and fertilized with various manure sources.

\section{MATERIALS AND METHODS}

The experiment was performed at the Experimental Station of the Instituto Agronômico de Pernambuco (08 $14{ }^{\circ} 18^{\prime}$ 'S, 35 $55^{\circ} 20^{\prime \prime} \mathrm{W}$; altitude of $537 \mathrm{~m}$ ) in Caruaru, PE, Brazil. The local climate is classified as BSh on the Köppen climate classification, specifically as a hot semi-arid climate, with an average annual precipitation of $694 \mathrm{~mm}$. The soil in the experimental area is classified as Regolithic
Neosoil. A $0-20 \mathrm{~cm}$ layer of soil was analyzed via the methodology described by EMBRAPA (2011), yielding the following chemical characteristics: $\mathrm{pH}$ $\left(\mathrm{H}_{2} \mathrm{O}\right)=4.7 ; \mathrm{Ca}^{2+}=1.85 \mathrm{cmol}_{\mathrm{c}} \mathrm{dm}^{-3} ; \mathrm{Mg}^{2+}=0.42 \mathrm{cmol}_{\mathrm{c}}$ $\mathrm{dm}^{-3} ; \mathrm{K}^{+}=0.15 \mathrm{cmol}_{\mathrm{c}} \mathrm{dm}^{-3} ; \mathrm{Na}^{+}=0.07 \mathrm{cmol}_{\mathrm{c}} \mathrm{dm}^{-3} ; \mathrm{Al}^{3+}$ $=0.27 \mathrm{cmol}_{\mathrm{c}} \mathrm{dm}^{-3}$; P (Mehlich-1) $=19.5 \mathrm{mg} \mathrm{dm}^{-3}$; and organic matter $=16.5 \mathrm{~g} \mathrm{~kg}^{-1}$.

The experiment was performed using a randomized block design with subdivided plots and four replicates. The primary plot consisted of the following cropping systems: IPA-Sertânia intercropped with leucaena, IPA-Sertânia intercropped with gliricidia, and the cactus in its isolated form. The plots measured $30 \mathrm{~m} \times 16 \mathrm{~m}$. The subplots were divided by fertilizer, with the following manure sources: cattle, sheep, goat, and broiler litter. These covered areas of $30 \mathrm{~m} \times 4 \mathrm{~m}$.

The cactus used in this study was planted in March of 2011, at a spacing of $1 \mathrm{~m} \times 0.25 \mathrm{~m}$, while the legumes were distributed in three double-rows per plot, at a spacing of $9 \mathrm{~m}$ between each pair, $1 \mathrm{~m}$ between the rows constituting a pair, and $0.5 \mathrm{~m}$ between plants in the same row. Fertilization was based on total $\mathrm{N}$ concentration, following the recommendation of $200 \mathrm{~kg} \mathrm{ha}^{-1}$ of $\mathrm{N}$ and correcting the dry matter concentration of the manure. Manure was applied in 2012 and 2013, while the cactus was harvested at the end of each year, and in 2015. Manures were distributed between the cactus lines, excluding the double-rows of legumes.

The cacti were collected in April 2016, with the original portions preserved after each cut. In the intercropped cultivation group, plants were harvested at a distance of $1,2,3$, and $4 \mathrm{~m}$ from the legumes, with 2 plants/distances/subplots being sampled. For the isolated cultivation group, this corresponded to 4 plants/subplots. The plants were weighed in the field. One composite sample was made and pre-dried in a forced air circulation oven at $55^{\circ} \mathrm{C}$ until reaching a constant weight (SILVA \& QUEIROZ, 2009). Dry matter production (DMP) was calculated based on the plant density per subplot.

$\mathrm{N}$ concentration was obtained via dry combustion, using the Dumas method (Vario Micro Cube, Elementar, Hanau, Germany). To determine $\mathrm{P}, \mathrm{K}, \mathrm{Ca}$, and $\mathrm{Mg}$ concentration, the samples were digested in a mixture of nitric acid and perchloric acid $(5: 1 \mathrm{~mL})$ and analyzed according to the methodology described by BEZERRA NETO \& BARRETO (2004).

Analysis of variance was carried out using PROC MIXED by SAS (SAS, 1999). The fixed effects were the cropping system, manure sources, 
and distances of the legume double-rows. The block was analyzed as a random effect. When the F-test was significant, the treatment means were compared using Tukey's test at 5\% probability. Collection distances were submitted to regression analysis.

\section{RESULTS AND DISCUSSION}

No differences were observed in the production of cactus dry matter between the studied cropping systems (Table 1). This is likely the case due to the residual effect of fertilizing in 2012, 2013, and 2015 with the same manure sources. Given the passage of five years after establishing the intercropping, these results demonstrated that both the sources and the quantity of utilized manure were adequate, to the effect that the residual influence of the manure reduced the competitive effect of the legumes on the cactus.

$\mathrm{P}$ and $\mathrm{K}$ concentrations differed $(\mathrm{P}<0.05)$ between the cropping systems (Table 1). Cactus $\mathrm{P}$ concentration in the gliricidia samples was greater than in the leucaena samples but did not differ from the isolated samples. This could be the result of lower deposition and contribution of this nutrient from the leadtree litter, as observed by BERTALOT et al. (2004). The greatest concentration of $\mathrm{K}$ was obtained with the isolated samples, which could be the result of the absence of competition and the high demand for this nutrient by the cactus (DUBEUX JÚNIOR et al., 2006). However, this value did not differ $(\mathrm{P}<0.05)$ from that of the gliricidia sample, likely due to the higher concentrations of this nutrient in the upper part of the gliricidia (BARRETO \& FERNANDES, 2001). These results indicated that gliricidia contributes to $P$ and $\mathrm{K}$ concentrations in intercropping with the cactus.

A correlation was observed $(\mathrm{P}<0.05)$ between distances between the legume and manure lines and production of cactus dry matter and $\mathrm{N}$ concentration (Table 2). The greatest cactus production was obtained at $1 \mathrm{~m}$ using cattle and sheep manure. A regression analysis of these samples showed a quadratic effect $(\mathrm{P}<0.05)$, indicating a decrease in production at $2 \mathrm{~m}$, with an increase after 3 and $4 \mathrm{~m}$. The greatest production being at the lowest distance might be the result of greater legume litter deposits (SILVA et al., 2013) and the greater application of manure and; consequently, macronutrients. Conversely, this greater quantity could have yielded improvements in the soil properties, such as greater retention of humidity and water availability (SILVA et al., 2004), which would in turn favor nutrient absorption and, consequently, greater production.

Regression analysis of the broiler litter fertilizer showed a linear effect $(\mathrm{P}<0.05)$, indicating a reduction in the production of dry matter as legume distance increased. This is likely due to a decrease in overall manure and litter deposition at increased distances. Meanwhile, regression analysis of cactus $\mathrm{N}$ concentration (Table 2) was not significant for either a linear or quadratic effect with respect to distance for any manure. $\mathrm{N}$ concentration differed with distance for goat manure and broiler litter, with the lowest values observed for a legume distance of $2 \mathrm{~m}$. However, for cattle and sheep manure, no differences were observed with respect to distance. These observations may result from a low or nonexistent contribution made by legumes to biological $\mathrm{N}$ fixation, which could have resulted from the fact that rainfall in the years preceding cactus harvesting was lighter than normal for the area. Moreover, the supply of organic $\mathrm{N}$ in the soil solution from fertilizing with manure could have inhibited symbiosis between plant roots and $\mathrm{N}$ fixing bacteria.

Generally, the greatest $\mathrm{N}$ concentrations were obtained with broiler litter, likely due to the

Table 1 - Dry matter production (DMP) and phosphorus (P) and potassium (K) concentration in IPA-Sertânia cactus cultivated in different cropping systems in Caruaru, PE.

\begin{tabular}{|c|c|c|c|}
\hline Cropping systems & DMP & $\mathrm{P}$ & $\mathrm{K}$ \\
\hline & -----------Mg ha'-1 2 years ${ }^{-1}$----------- & --------------------- & 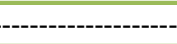 \\
\hline Cactus intercropped with Gliricidia & $20.5 \mathrm{~A}$ & $3.80 \mathrm{~A}$ & $29.02 \mathrm{AB}$ \\
\hline Cactus intercropped with Leucaena & $21.2 \mathrm{~A}$ & 2.79B & $23.55 \mathrm{~B}$ \\
\hline Cactus cultivated alone & $24.5 \mathrm{~A}$ & $3.45 \mathrm{AB}$ & $30.56 \mathrm{~A}$ \\
\hline Standard error & 1.5 & 0.27 & 2.54 \\
\hline
\end{tabular}

Identical uppercase letters in columns do not differ by Tukey’s test at $5 \%$ probability. 
Table 2 - Dry matter production (DMP) and nitrogen $(\mathrm{N})$ concentration in IPA-Sertânia cactus at different distances between doublerows of legumes and manure sources in Caruaru, PE.

\begin{tabular}{|c|c|c|c|c|}
\hline \multicolumn{5}{|c|}{ 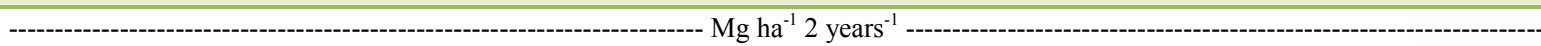 } \\
\hline Distances & Cattle & Goat & Sheep & Broiler litter \\
\hline $1 \mathrm{~m}$ & $28.3 \mathrm{a}$ & $21.8 \mathrm{a}$ & $27.9 \mathrm{a}$ & $19.2 \mathrm{a}$ \\
\hline $2 \mathrm{~m}$ & $16.3 \mathrm{a}$ & $19.8 \mathrm{a}$ & $18.0 \mathrm{a}$ & $19.1 \mathrm{a}$ \\
\hline $3 \mathrm{~m}$ & $17.0 \mathrm{a}$ & $21.0 \mathrm{a}$ & $20.8 \mathrm{a}$ & $16.9 \mathrm{a}$ \\
\hline $4 \mathrm{~m}$ & $20.9 \mathrm{a}$ & $22.5 \mathrm{a}$ & $21.3 \mathrm{a}$ & $14.6 \mathrm{~b}$ \\
\hline Standard error & 2.0 & 2.0 & 2.0 & 2.0 \\
\hline Linear effect & 0.0114 & 0.7213 & 0.1259 & 0.0123 \\
\hline Quadratic effect & 0.0001 & 0.4107 & 0.0413 & 0.4287 \\
\hline \multicolumn{5}{|c|}{ 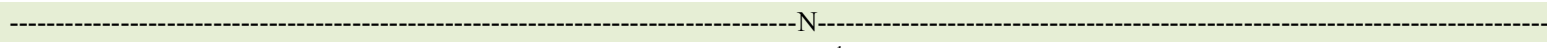 } \\
\hline \multicolumn{5}{|c|}{ 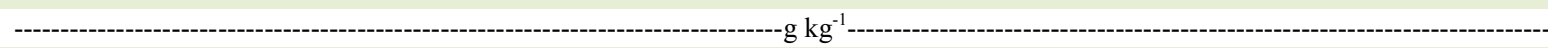 } \\
\hline $1 \mathrm{~m}$ & 9.47Aab & 10.39Aab & $9.25 \mathrm{Ab}$ & $11.07 \mathrm{ABa}$ \\
\hline $2 \mathrm{~m}$ & $9.04 \mathrm{Aab}$ & $7.81 \mathrm{Bb}$ & 9.61Aa & $10.40 \mathrm{Ba}$ \\
\hline $3 \mathrm{~m}$ & $9.07 \mathrm{Ab}$ & $9.67 \mathrm{Ab}$ & $8.49 \mathrm{Ab}$ & $12.01 \mathrm{Aa}$ \\
\hline $4 \mathrm{~m}$ & 9.61Aab & $9.40 \mathrm{Aab}$ & $9.02 \mathrm{Ab}$ & $10.99 \mathrm{ABa}$ \\
\hline Standard error & 0.69 & 0.69 & 0.69 & 0.69 \\
\hline Linear effect & 0.7893 & 0.6678 & 0.3990 & 0.7056 \\
\hline Quadratic effect & 0.2026 & 0.0531 & 0.8535 & 0.8265 \\
\hline
\end{tabular}

Identical letters, uppercase in columns and lowercase in lines, do not differ by Tukey's test at 5\% probability.

more rapid decomposition and accompanying release of $\mathrm{N}$ inherent to this material. SILVA et al. (2014), when evaluating cattle manure and broiler litter in Red-Yellow Acrisol, reported a more rapid decomposition in the first 30 days for the broiler litter. This was accompanied by a faster initial release of $\mathrm{N}$, which slowed down in the subsequent periods.

Legume distance affected $(\mathrm{P}<0.05) \mathrm{K}$ and $\mathrm{Mg}$ concentrations in the cactus (Table 3 ). $\mathrm{K}$ concentration varied linearly. Regression analysis indicated a decrease in concentration as distance increased, seeing how the greatest deposition of litter and nutrients occurs in the bands closest to the trees. Conversely, $\mathrm{Mg}$ concentration showed a quadratic effect, with a decrease at $2 \mathrm{~m}$; this may be because, at this distance, there is greater competition with the legumes for this nutrient.

Manure source had an effect $(\mathrm{P}<0.05)$ on $\mathrm{N}, \mathrm{K}, \mathrm{Ca}$, and $\mathrm{Mg}$ cactus concentrations (Table 4). Although, fertilizing was performed based on $\mathrm{N}$

Table 3 - Potassium (K) and magnesium (Mg) concentration in IPA-Sertânia cactus at different distances between double-rows of legumes in Caruaru, PE.

\begin{tabular}{|c|c|c|}
\hline Distances & $\mathrm{K}$ & $\mathrm{Mg}$ \\
\hline & \multicolumn{2}{|c|}{----------------------------------------------'g kg${ }^{-1}$ '------------------------------------------- } \\
\hline $1 \mathrm{~m}$ & 30.10 & 8.9 \\
\hline $2 \mathrm{~m}$ & 26.12 & 7.0 \\
\hline $3 \mathrm{~m}$ & 25.28 & 7.3 \\
\hline $4 \mathrm{~m}$ & 23.59 & 7.4 \\
\hline Standard error & 3.07 & 0.8 \\
\hline Linear effect & $<0.0001$ & 0.0154 \\
\hline Quadratic effect & 0.3005 & 0.0063 \\
\hline
\end{tabular}


Table 4 - Nitrogen $(\mathrm{N})$, potassium $(\mathrm{K})$, calcium $(\mathrm{Ca})$, and magnesium $(\mathrm{Mg})$ concentration in IPA-Sertânia cactus fertilized with different manure sources in Caruaru, PE.

\begin{tabular}{|c|c|c|c|c|}
\hline Manure & $\mathrm{N}$ & $\mathrm{K}$ & $\mathrm{Ca}$ & $\mathrm{Mg}$ \\
\hline \multicolumn{5}{|c|}{ 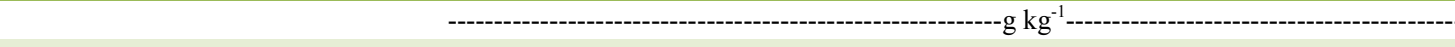 } \\
\hline Cattle & $9.03 \mathrm{~B}$ & 29.79A & $15.4 \mathrm{~B}$ & $8.4 \mathrm{~A}$ \\
\hline Goat & $9.04 \mathrm{~B}$ & $29.01 \mathrm{~A}$ & $18.9 \mathrm{~A}$ & $7.6 \mathrm{~A}$ \\
\hline Broiler litter & $10.57 \mathrm{~A}$ & $25.49 \mathrm{~B}$ & 14.7B & $6.1 \mathrm{~B}$ \\
\hline Sheep & $8.88 \mathrm{~B}$ & $26.56 \mathrm{AB}$ & $16.3 \mathrm{AB}$ & $7.7 \mathrm{~A}$ \\
\hline Standard error & 0.56 & 2.38 & 0.7 & 0.6 \\
\hline
\end{tabular}

Identical uppercase letters in columns do not differ by Tukey’s test at $5 \%$ probability.

concentration, following the recommendation of $200 \mathrm{~kg} \mathrm{ha}^{-1}$, the greatest quantities of this nutrient were obtained using broiler litter, likely as a function of the more rapid decomposition. According to MINSON (1990), for normal rumen function, the crude protein concentration of forage should be, at least, $70 \mathrm{~g} \mathrm{~kg}^{-1}$, or $11.2 \mathrm{~g} \mathrm{~kg}^{-1}$ of $\mathrm{N}$ in dry matter. However, the average $\mathrm{N}$ values reported in this study were lower than those indicated. As such, it will be necessary to include dietary supplements with protein sources, such as legumes, not only in order to increase dry matter and protein intake, but also to correct for the diarrhea that would result when this food source is supplied alone or consumed freely (GALVÃO JÚNIOR et al., 2014).

Generally, cactus $\mathrm{K}, \mathrm{Ca}$, and $\mathrm{Mg}$ concentration were lower when using broiler litter as a fertilizer given the lower applied quantity of this manure and; consequently, the lower amount of other macronutrients.

\section{CONCLUSION}

Intercropping IPA-Sertânia cactus with leucaena or gliricidia, or cultivating it alone, does not influence DMP, but influences the composition of macronutrients in the cactus, with the best results obtained for cactus cultivated alone and with gliricidia.

The distance between the legume rows and the manure sources utilized for fertilizing influences production and $\mathrm{N}$ concentration in cactus that is intercropped with leucaena and gliricidia.

\section{DECLARATION OF CONFLICTING INTERESTS}

The authors declare no conflict of interest. The founding sponsors had no role in the design of the study; in the collection, analyses, or interpretation of data; in the writing of the manuscript, and in the decision to publish the results.

\section{ACKNOWLEDGEMENTS}

The authors appreciated the CNPq fellowship provided to Dr. Mercia Santos and Dr. Alexandre Mello and the Graduate Assistantship funded by FACEPE to fund the PhD of Dr. Karina Miranda.

\section{REFERENCES}

BARRETO, A.C.; FERNANDES, M.F. Use of Gliricidia sepium and M Leucaena leucocephala in alley cropping systems to improve Brazilian coastal tableland soils. Pesquisa Agropecuária Brasileira, Brasília, v.36, n.10, p.1287-1293, 2001. Available from: $<$ http://www.scielo.br/scielo.php?script $=$ sci_arttext\&pid=S0100204X2001001000011>. Accessed: Mar. 15, 2018. doi: 10.1590/ S0100-204X2001001000011.

BERTALOT, M.J.A.; GUERRINI, I.A.; MENDOZA, E.; DUBOC, E.; BARREIROS, R.M.; CORRÊA, F.M. Soil nutrients return via litter fall deposition of four leguminous tree species in the region of Botucatu - São Paulo, Brazil. Scientia Forestalis, v.65, p.219227, 2004. Available from: <http://hdl.handle.net/11449/67757>. Accessed: Mar. 15, 2018.

BEZERRA NETO, E.; BARRETO, L.P. Métodos de Análises Químicas em Plantas. Recife, UFRPE, Imprensa Universitária. 165p. 2004.

DUBEUX JÚNIOR, J.C.B.; SANTOS, M.V.F. dos; LIRA, M. de A.; SANTOS, D.C. dos; FARIAS, I.; LIMA, L.E.; FERREIRA, R.L.C. Productivity of Opuntia ficus-indica (L.) Miller under different $\mathrm{N}$ and $\mathrm{P}$ fertilization and plant population in northeast Brazil. Journal of Arid Environments, v.67, p.357-372, 2006. Available from: $<$ https://www.sciencedirect.com/science/article/ abs/pii/S0140196306000784>. Accessed: Mar. 16, 2018. doi: 10.1016/j.jaridenv.2006.02.015.

EDWARDS, A.; et al. Yield, chemical composition and in vitro ruminal fermentation of the leaves of Leucaena Leucocephala, Gliricidia Sepium and Trichanthera Gigantea as influenced by harvesting frequency. Journal of Animal Science Advances, 
v.2, suppl. 3.2, p.321-331, 2012. Available from: <https://www. sciencedirect.com/science/article/abs/pii/S0140196306000784>. Accessed: Mar. 16, 2018. doi: 10.1016/j.jaridenv.2006.02.015.

EMBRAPA - Empresa Brasileira de Pesquisa Agropecuária. Centro Nacional de Pesquisas de Solos. Manual de métodos de análises de solos. 2.ed. Rio de Janeiro: Embrapa Solos, 2011. 230p.

FERREIRA, M.A.; et al. The use of cactus as forage for dairy cows in semi-arid regions of Brazil. In: Petr Konvalina (Ed.), Organic Farming and Food Production. InTech, South Bohemia, p.1-22, 2012. Available from: $<$ http://www.scielo.br/scielo.php?script $=$ sci abstract\&pid $=$ S1516-35982009001300032\&lng $=$ es\&nrm $=\mathrm{i}=>$. Accessed: May 20, 2018. doi: 10.1590/S1516-35982009001300032.

GALVÃO JÚNIOR, J.G.B.; et al. Cactus in ruminant feeding: culture and use. Acta Veterinaria Brasilica, v.8, n.2, p.7885, 2014. Available from: <https://www.researchgate.net/ publication/287191230_Cactus_in_ruminant_feeding Culture and use $>$. Accessed: May 02, 2018. doi: 10.21708/ avb.2014.8.2.3490.

LOPES, E.B.; et al. Selection of cactus pear forage (Opuntia spp.) and (Nopalea spp.) genotypes resistant to the carmine cochineal (Dactylopius opuntiae Cockerell, 1929) in the state of Paraíba, Brazil. Engenharia Ambiental, v.7, n.1, p.204-215, 2010. Available from: $<$ https://www.researchgate.net/publication/43339482_Selection of Cactus Pear Forage Opuntia spp and Nopalea spp Genotypes_resistant_to_the_Carmine_Cochineal_Dactylopius_ opuntiae_cockerel1_1929_in_the_State_of_Paraiba_Brazil $>$. Accessed: Mar. 15, 2018.

RAMOS, J.P. de F.; et al. Effects of harvest management and manure levels on cactus pear productivity. Revista Caatinga, v.28, n.2, p.135-142, 2015. Available from: <https://periodicos.ufersa.edu.br/ index.php/caatinga/article/view/3735>. Accessed: Mar. 15, 2018.
SAS. Inst. Inc. SAS statistics user's guide. Release version 6. SAS Ins. Inc., Cary, NC. 1999.

SANTOS, D.C. et al. Production and chemical composition of forage palm cv. (Opuntia ficus-indica Mill) under fertilization and liming, in the semi-arid region of Pernambuco. Pesquisa Agropecuária Pernambucana, v. esp., n.9, p.69-78, 1996.

SILVA, J. da; et al. The effect of cattle manure on yield of green corn ears and maize grains. Horticultura Brasileira, v.22, p.326-331, 2004. Available from: <http://www.scielo.br/pdf/hb/v22n2/21041.pdf $>$. Accessed: Mar. 15, 2018. doi: 10.1590/S0102-05362004000200033.

SILVA, D.J.; QUEIROZ, A.C. Análise de alimentos: métodos químicos e biológicos. 3.ed. Viçosa: UFV, 2009. 235p.

SILVA, A.B. et al. Soil litter stock and fertility after planting leguminous shrubs and forage trees on degraded signal grass pasture. Revista Brasileira de Ciência do Solo, v.37, n.2, p.502-511, 2013. Available from: <http://www.scielo.br/scielo.php?script=sci_artte xt\&pid=S0100-06832013000200021 >. Accessed: Mar. 15, 2018. doi: 10.1590/S0100-06832013000200021.

SILVA, V.B. da; et al. Decomposition and mineralization of N, P and $\mathrm{K}$ of cattle manure and poultry litter isolated or mixed. Revista Brasileira de Ciência do Solo, v.38, p.1537-1546, 2014. Available from: $\quad<$ http://www.scielo.br/scielo.php?script=sci_arttext\&pid $=$ S0100-06832014000500019>. Accessed: May 02, 2018. doi: 10.1590/S0100-06832014000500019.

SILVA, N.G.M. et al. Effects of planting density and organic fertilization doses on productive efficiency of cactus pear. Revista Caatinga, v.29, p.976-983, 2016. Available from: $<$ http://www.scielo.br/scielo.php?script=sci_arttext\&pid $=$ S1983-21252016000400976 $>$. Accessed: May 02, 2018. doi: 10.1590/1983-21252016v29n423rc. 